\title{
Influence of Pre Harvest Factor on Post-Harvest Quality of Green Sweet Corn at Ambient Condition (Zea mays convar. saccharata. rugosa) Cultivar, Madhuri
}

\author{
Bharat H. Panchal", V.K. Patel and R.A. Khimani \\ Department of Horticulture, B.A. College of Agriculture, Anand Agricultural University, \\ Anand, Gujarat, India \\ *Corresponding author
}

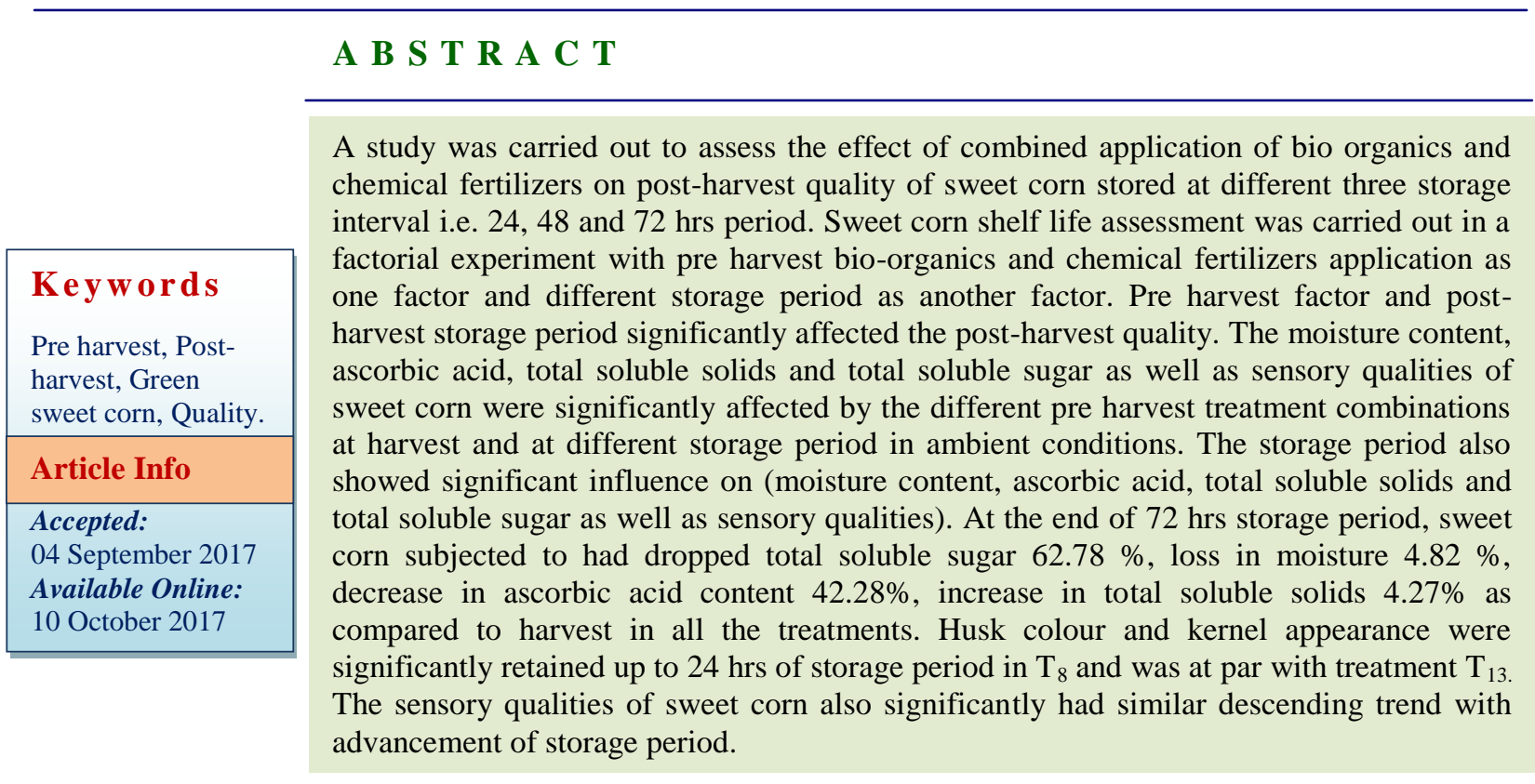

\section{Introduction}

Corn was probably gathered from the wild millennia before being domesticated some 7000 years ago. Sweet corn (Zea mays convar. saccharata. rugosa), a diploid species with $2 \mathrm{n}=20$ chromosomes, is a member of the grass family (Grammineae), (Beadle, 1939, Wolfe et al., 1997). The major difference between sweet corn and field corn is its genetic makeup rather than systematic or taxonomic characterization. Sweet corn has the gene "su" at the "sugary" locus on chromosome one which prevents the conversion of a part of sugars into starch. Therefore, sweet corn produces and retains large amounts of sugar in the kernels, hence it is named as 'sweet'. Sweet corn is of relatively recent origin and also called sugar corn and pole corn. Unlike field corn varieties, which are harvested when the kernels are dry and mature, sweet corn is picked when immature (milk stage) and prepared and eaten as a vegetable, rather than a grain. Sweet corn is the most popular vegetable in countries like USA and Canada. 
Roasted green cobs provide starch, fat, protein, sugar, minerals and vitamins palatable and digestible form of relatively low cost.

There is sufficient evidence that the intensive agriculture systems have also caused decline in vitamins and mineral contents of fresh fruits and vegetables (Worthington, 2001). The beneficial effect of vermicompost organic manures and biofertilizers in improving soil fertility and productivity is well documented. In addition, it also supplies plant growth promoting substances, humus forming microbes and $\mathrm{N}$-fixers in the soil (Baran et al., 1998). Sweet corn has one of the highest metabolic and respiration rates among vegetable crops, which makes it a very perishable product prone to rapid post-harvest deterioration caused by kernel desiccation, loss of sweetness, husk discoloration and development of decay that requires special attention to the post-harvest practices used in order to prolong its shelf life. On other hand, fresh produce with less chemical residues will be a boon for the public health (Chaudhary et al., 2004). Some ecological, cultural and physical factors including fertilizer management have significant influence on the chemical and nutritional composition of plants as well as their anatomical and morphological structure (Salunkhe and Kadan, 2005). It has been proven that pre harvest factors have a great impact on postharvest quality with application of ideal pre harvest treatments which, ensures better postharvest quality.

However, at present, information on impact of pre harvest factors on post-harvest quality is lacking. Therefore, a field as well as a laboratory trial conducted with an objective to study the influence of pre harvest factor on biochemical changes and physical appearance of green sweet corn at an ambient storage (Zea mays convar. saccharata. rugosa) cultivar, Madhuri.

\section{Material and Methods}

An experiment was conducted at the Main Maize Research Station, Anand Agricultural University, Godhra during rabi season 200506 and 2006-07 with an objective to explore significance of an integrated agro technology in maintenance of postharvest quality and nutritional value of fresh sweet corn. The experiment was laid out with 15 treatments comprised of 12 combinations with additional three treatments i.e. $\mathrm{T}_{13}$ (application of $10 \mathrm{t}$ $\mathrm{ha}^{-1} \mathrm{FYM}+2.5 \mathrm{t} \mathrm{ha}^{-1} \mathrm{VC}$ and seed inoculated with biofertilizers), $\mathrm{T}_{14}$ (application of $100 \%$ RDF and seed inoculated with biofertilizers) and treatment $\mathrm{T}_{15}$ as control (application of 100\% RDF (120:40:0 kg NPK ha $\left.{ }^{-1}\right)$ through chemical fertilizers). (A) Organic Sources: (1) Farmyard Manure:10 t/ha $\left[\mathrm{F}_{1}\right]$ (2) Vermicompost: $2.5 \mathrm{t} / \mathrm{ha} \quad\left[\mathrm{V}_{1}\right], \quad$ (B) Fertilizers (Chemical Fertilizers) (1) $100 \%$ of recommended dose, i.e., 120-40-0: $\mathrm{N}, \mathrm{P}_{2} \mathrm{O}_{5}$ and $\mathrm{K}_{2} \mathrm{O} \quad \mathrm{kg} \mathrm{ha}^{-1}\left[\mathrm{C}_{1}\right]$, (2) $75 \%$ of recommended dose, i.e., 90-30-0: $\mathrm{N}, \mathrm{P}_{2} \mathrm{O}_{5}$ and $\mathrm{K}_{2} \mathrm{O} \mathrm{kg} \mathrm{ha}{ }^{-1}\left[\mathrm{C}_{2}\right]$, (3) $50 \%$ of recommended dose, i.e., 60-20-0: $\mathrm{N}, \mathrm{P}_{2} \mathrm{O}_{5}$ and $\mathrm{K}_{2} \mathrm{O} \mathrm{kg} \mathrm{ha}^{-1}$ $\left[\mathrm{C}_{3}\right]$, (C) Biofertilizers (1) Control $\left[\mathrm{B}_{0}\right]$ (2) Azotobacter-1 + PSB-16 : each of $25 \mathrm{~g} \mathrm{~kg}^{-1}$ seed $\left[\mathrm{B}_{1}\right]$.

Tender cobs harvested from central two row of each net plot of experiment were used for the present study. The green sweetcorn cobs were stored at room temperature to create a condition, which was normally occurs in the commercial market place and farmer's home to study the physico-chemical changes in ambient storage condition. Observations were taken for viz., Moisture, Total soluble salts, Total soluble sugar, Ascorbic acid at three storage interval i.e. $24 \mathrm{hrs}, 48 \mathrm{hrs}$ and $72 \mathrm{hrs}$ at ambient storage condition. Kernels removed from the mid-section of the cob were used for moisture TSS, sugar, and ascorbic acid. The moisture content of kernels at harvest and at different storage period was determined by 
using the hot air oven method. Total soluble solids (TSS) were recorded by using ERMA hand refractometer with a range of 0 to $32^{\circ}$ brix. Total soluble sugar content of kernel of green sweet corn cobs was determined by anthrone reagent method described by Franscistt et al., (1971). Ascorbic acid content of kernel of green cobs of sweet corn was determined by 2, 4 dinitro phenyl hydrazine (DNPH) method.

Uniform matured five cobs were rated for sensory evaluation. The sensory evaluation of sweet corns cob, under different treatments were done by a panel of experts judges related to maize research on the basis of scale, where 5 scale was given to excellent to 1 very poor. For experiment on post-harvest study of sweet corn the design adopted for experiment was randomized block design with factorial concept. Comparisons of the treatment means were done by using Duncan's Multiple Range Test at $\mathrm{P}<0.05 \%$ level of significance (Duncan, 1955).

\section{Results and Discussion}

\section{Moisture}

At harvest significantly higher moisture content of kernel was found in treated with $\mathrm{T}_{13}\left(\mathrm{~V}_{2.5}+\mathrm{F}_{10}+\mathrm{B}_{1}\right)$ followed by $\mathrm{T}_{14}, \mathrm{~T}_{10}$ and $\mathrm{T}_{8}$ as compared to rest of treatments. Significant variation was observed in moisture content among treatments and storage period. Data indicated (Table 1) that at the end of storage period, treatment $\mathrm{T}_{14}\left(\mathrm{~F}_{0}\right.$ $\mathrm{V}_{0}+100 \% \mathrm{RDF}+\mathrm{B}_{1}$ ) registered significantly the higher moisture content $(70.85 \%)$ followed by $\mathrm{T}_{13}\left(\mathrm{~V}_{2.5}+\mathrm{F}_{10}+\mathrm{B}_{1}\right), \mathrm{T}_{10}\left(\mathrm{~V}_{2.5}+\right.$ $\left.75 \% \mathrm{RDF}+\mathrm{B}_{1}\right)$ and $\mathrm{T}_{8}\left(\mathrm{~V}_{2.5}+100 \% \mathrm{RDF}+\right.$ $\mathrm{B}_{1}$ ) as compared to rest of treatments. There is gradual decline in moisture content was found in all the treatment with advancement of storage period. The mean percent loss in moisture at the end of 24, 48 and $72 \mathrm{hrs,} \mathrm{were}$
$1.80,3.04$ and 4.82 percent from all the treatments. The possible reason might be due to higher rate of transpiration in ambient storage condition leading to moisture loss. These results were in agreement with those reported by Wann et al., (1971) and Deak et al., (1987) in sweetcorn. Similar trend in Kinnow fruit during storage under ambient condition was also been reported by Thakur et al., (2002).

\section{Total soluble sugar}

Changes in total soluble sugar content of sweet corn in response to different treatments were observed. Data presented in (Table 1) revealed that the highest total soluble sugar was found at harvest stage of sweet corn that received $\mathrm{T}_{8}\left(\mathrm{~V}_{2.5}+100 \% \mathrm{RDF}+\mathrm{B}_{1}\right)$ i.e. $21.05 \%$ followed by $\mathrm{T}_{8}$ as compared to rest of treatments. This might be due to application of organic manure with the inorganic fertilizers and seed inoculation of biofertilizers which leads to supply of major and micro nutrient thereby increased in total sugar. Further, supplying inorganic fertilizers to sweet corn plants with vermicompost and biofertilizers may lead to enhance accumulation and maintenance of total sugar in the kernel of sweet corn during the storage. Similar results were reported by Hailu et al., (2005) in carrot and Melkamu et al., (2008) in tomato.

There was significant net mean dropped of $54.45 \%$ total sugar of green sweet corn in 24 hrs, from initial level after that mean gradual decline of total sugar was found at the end of 72 hrs i.e. $62.78 \%$ in all the treatments under ambient storage condition. Further treatment $\mathrm{T}_{8}\left(\mathrm{~V}_{2.5}+100 \% \mathrm{RDF}+\mathrm{B}_{1}\right)$ recorded significantly the higher sugar $11.77 \%$ at the end of storage was at par with $\mathrm{T}_{10}\left(\mathrm{~V}_{2.5}+75 \%\right.$ $\left.\mathrm{RDF}+\mathrm{B}_{1}\right), \mathrm{T}_{2}\left(\mathrm{~F}_{10}+100 \% \mathrm{RDF}+\mathrm{B}_{1}\right), \mathrm{T}_{7}$ $\left(\mathrm{V}_{2.5}+100 \% \mathrm{RDF}+\mathrm{B}_{0}\right)$ and $\mathrm{T}_{1}\left(\mathrm{~F}_{10}+100 \%\right.$ $\mathrm{RDF}+\mathrm{B}_{0}$ ) were noted 11.31, 11.14, 11.08 
and $11.03 \%$ respectively and which were significantly higher over control $\mathrm{T}_{15}$ (10.21\%). The treatments $\mathrm{T}_{8}$ recorded significantly higher total sugar at fresh as well as at the end of 24,48 and $72 \mathrm{hrs}$, were $21.05 \%, \quad 9.59 \%, \quad 8.37 \%$ and $8.18 \%$ respectively during all the successive storage period over the control $\mathrm{T}_{15}$. This might be due to respiration an important factor in accelerating the depletion of sugar from green sweet corn.

Respiration heat will raise the temperature on the inside of large piles of green corn to a very marked degree. Increased temperature accelerates not only the respiratory process itself but also the other processes responsible for most of the sugar loss. Furthermore, the sugar is converted into starch or other polysaccharides, hydrolyzed by dilute acids during storage due to high temperature. This result are close conformity with an earlier reported by Appleman and Arthur (1919) in sweet corn, Garwood and MaArdle (1976), Olsen et al., (1990) and Brecht et al., (1990) in sweet corn.

\section{Total soluble solids}

Total soluble solids (TSS) of sweet corn significantly increased with advancement of storage period upto $48 \mathrm{hrs}$ and after that declined in all the treatments (Table 1). Significant variation was observed in TSS content among treatments and storage period. Treatment $\mathrm{T}_{13}\left(\mathrm{~V}_{2.5}+\mathrm{F}_{10}+\mathrm{B}_{1}\right)$ recorded significantly higher TSS (17.78 ${ }^{\circ}$ brix $)$ followed by $\mathrm{T}_{10}\left(\mathrm{~V}_{2.5}+75 \% \mathrm{RDF}+\mathrm{B}_{1}\right), \mathrm{T}_{8}$ $\left(\mathrm{V}_{2.5}+100 \% \mathrm{RDF}+\mathrm{B}_{1}\right)$ and $\mathrm{T}_{2}\left(\mathrm{~F}_{10}+100 \%\right.$ $\mathrm{RDF}+\mathrm{B}_{1}$ ) were $17.69,17.66$ and $17.42^{\circ}$ brix respectively as compared to control $\mathrm{T}_{15}(16.34$ obrix).

The treatments $T_{10}, T_{13}$ and $T_{8}$ were recorded significantly higher TSS at the end of 24, 48 and then after found decline in TSS at the end of $72 \mathrm{hrs}$ storage over the control $\mathrm{T}_{15}$. The magnitude of increases in TSS at initial to 24 hrs and $48 \mathrm{hrs}$ were $2.19 \%$ and $4.27 \%$ after decline was registered i.e. $1.04 \%$ at $72 \mathrm{hrs}$. This might be due to dehydration under ambient condition. This result was in accordance with those reported by Deak et al., (1987) in sweet corn.

Thakur et al., (2002) reported increase in TSS in Kinnow might be the result of more water loss from fruit through transpiration process under ambient storage due to low atmospheric humidity and temperature condition, simultaneously the hydrolysis of polysaccharides occurred during storage. Similar trend was reported by Vani (2002) in baby corn and Hailu et al., (2008) in carrot.

\section{Ascorbic acid}

Ascorbic acid (AA) content of sweet corn over $72 \mathrm{hrs}$ storage period at ambient temperatures is shown in table 1 . Significant difference was observed in ascorbic acid content of sweet corn in response to pre harvest fertilizer treatments both at harvest \& during the storage period of $72 \mathrm{hrs}$.

Treatment $\mathrm{T}_{13} \quad$ i.e. application of vermicompost @ 2.5 tha $^{-1}$ + FYM 10tha ${ }^{-1}$ and seed inoculation with biofertilizers (ASA-1 + PSB-16) recorded significantly higher ascorbic acid content of sweet corn $(7.66 \mathrm{mg}$ $100^{-1} \mathrm{~g}$ ) followed by $\mathrm{T}_{8}$ and $\mathrm{T}_{10}(7.54$ and 7.58 $\mathrm{mg} 100^{-1} \mathrm{~g}$ ) as compared to the control treatment $\mathrm{T}_{15}\left(\mathrm{~F}_{0} \mathrm{~V}_{0}+100 \% \mathrm{RDF}+\mathrm{B}_{0}\right)$ i.e. $6.65 \mathrm{mg} 100^{-1} \mathrm{~g}$. Treatment $\mathrm{T}_{13}$ retained the highest ascorbic acid content throughout the successive storage period. The least ascorbic acid content of sweet corn was recorded both at the time of harvest and after 72 hrs of storage from the sweet corn subjected to pre harvest application of chemical fertilizer in treatment $\mathrm{T}_{15}$ 
Table.1 Moisture, Total sugar, Total soluble solids and Ascorbic acid as influenced by treatment and storage time at ambient condition. (Pooled data of two years i.e. the 2005-06 and 2006-07)

\begin{tabular}{|c|c|c|c|c|c|c|c|c|c|c|c|c|c|c|c|c|c|}
\hline \multirow{3}{*}{\multicolumn{2}{|c|}{ Treatments }} & \multicolumn{16}{|c|}{ Storage period (hours) } \\
\hline & & \multicolumn{4}{|c|}{ Moisture (\%) } & \multicolumn{4}{|c|}{ Total sugar $(\%)$} & \multicolumn{4}{|c|}{ Total soluble solids ( ${ }^{\circ}$ brix $)$} & \multicolumn{4}{|c|}{ Ascorbic acid $(\mathrm{mg} / 100 \mathrm{~g})$} \\
\hline & & \multirow{2}{*}{$\begin{array}{c}\text { O hrs. } \\
74.37\end{array}$} & \multirow{2}{*}{$\begin{array}{l}24 \mathrm{hrs} \\
73.12\end{array}$} & \multirow{2}{*}{$\begin{array}{l}48 \mathrm{hrs} \\
71.50\end{array}$} & \multirow{2}{*}{$\begin{array}{l}72 \mathrm{hrs} \\
69.97\end{array}$} & \multirow{2}{*}{$\begin{array}{c}\text { O hrs. } \\
19.74\end{array}$} & \multirow{2}{*}{$\begin{array}{c}24 \mathrm{hrs} \\
8.77\end{array}$} & \multirow{2}{*}{$\begin{array}{c}48 \mathrm{hrs} \\
7.82\end{array}$} & \multirow{2}{*}{$\begin{array}{c}72 \mathrm{hrs} \\
7.25\end{array}$} & \multirow{2}{*}{$\begin{array}{c}\text { O hrs. } \\
16.68\end{array}$} & \multirow{2}{*}{$\begin{array}{l}24 \mathrm{hrs} \\
17.00\end{array}$} & \multirow{2}{*}{$\begin{array}{l}48 \mathrm{hrs} \\
17.33\end{array}$} & \multirow{2}{*}{$\begin{array}{l}72 \mathrm{hrs} \\
16.93\end{array}$} & \multirow{2}{*}{$\begin{array}{l}\mathrm{O} \text { hrs. } \\
7.350\end{array}$} & \multirow{2}{*}{$\begin{array}{l}24 \mathrm{hrs} \\
5.930\end{array}$} & \multirow{2}{*}{$\begin{array}{l}48 \mathrm{hrs} \\
4.915\end{array}$} & \multirow{2}{*}{$\begin{array}{l}72 \mathrm{hrs} \\
4.371\end{array}$} \\
\hline $\mathrm{T}_{1}$ & $\mathrm{~F}_{10}+100 \% \mathrm{RDF}+\mathrm{B}_{0}$ & & & & & & & & & & & & & & & & \\
\hline $\mathrm{T}_{2}$ & $\mathrm{~F}_{10}+100 \% \mathrm{RDF}+\mathrm{B}_{1}$ & 75.30 & 74.01 & 71.65 & 70.27 & 20.15 & 9.29 & 7.91 & 7.39 & 17.10 & 17.38 & 17.88 & 17.33 & 7.510 & 5.990 & 5.025 & 4.380 \\
\hline $\mathrm{T}_{3}$ & $\mathrm{~F}_{10}+75 \% \mathrm{RDF}+\mathrm{B}_{0}$ & 74.16 & 72.85 & 71.24 & 69.39 & 19.06 & 8.15 & 7.15 & 6.92 & 15.90 & 16.35 & 16.90 & 16.35 & 7.280 & 5.840 & 5.005 & 4.380 \\
\hline $\mathrm{T}_{4}$ & $\mathrm{~F}_{10}+75 \% \mathrm{RDF}+\mathrm{B}_{1}$ & 74.16 & 72.87 & 71.40 & 69.38 & 19.39 & 8.98 & 7.88 & 7.56 & 16.55 & 16.98 & 17.33 & 16.83 & 7.325 & 5.885 & 4.945 & 4.380 \\
\hline $\mathrm{T}_{5}$ & $\mathrm{~F}_{10}+50 \% \mathrm{RDF}+\mathrm{B}_{0}$ & 74.16 & 72.83 & 71.30 & 70.14 & 17.63 & 7.44 & 5.93 & 5.75 & 14.98 & 15.43 & 15.80 & 15.38 & 6.950 & 4.730 & 3.940 & 3.385 \\
\hline $\mathrm{T}_{6}$ & $\mathrm{~F}_{10}+50 \% \mathrm{RDF}+\mathrm{B}_{1}$ & 74.53 & 73.21 & 71.43 & 69.27 & 17.96 & 7.99 & 6.60 & 6.33 & 15.50 & 15.85 & 16.23 & 15.73 & 7.235 & 5.735 & 4.825 & 4.350 \\
\hline $\mathrm{T}_{7}$ & $\mathrm{~V}_{2.5}+100 \% \mathrm{RDF}+\mathrm{B}_{0}$ & 75.08 & 73.61 & 71.81 & 69.90 & 19.95 & 8.50 & 7.50 & 7.31 & 16.75 & 17.33 & 17.78 & 17.35 & 7.360 & 5.890 & 4.860 & 4.315 \\
\hline $\mathrm{T}_{8}$ & $\mathrm{~V}_{2.5}+100 \% \mathrm{RDF}+\mathrm{B}_{1}$ & 75.35 & 74.08 & 72.62 & 70.46 & 21.05 & 9.59 & 8.37 & 8.18 & 17.38 & 17.93 & 17.95 & 17.38 & 7.540 & 6.020 & 4.915 & 4.360 \\
\hline $\mathrm{T}_{9}$ & $\mathrm{~V}_{2.5}+75 \% \mathrm{RDF}+\mathrm{B}_{0}$ & 74.96 & 73.73 & 72.35 & 70.02 & 19.53 & 9.23 & 7.52 & 7.29 & 15.98 & 16.30 & 16.65 & 16.08 & 7.340 & 5.820 & 5.045 & 4.390 \\
\hline $\mathrm{T}_{10}$ & $\mathrm{~V}_{2.5}+75 \% \mathrm{RDF}+\mathrm{B}_{1}$ & 75.42 & 74.05 & 71.93 & 70.55 & 20.68 & 9.61 & 7.82 & 8.05 & 17.35 & 17.78 & 18.23 & 17.40 & 7.575 & 6.020 & 4.865 & 4.355 \\
\hline $\mathrm{T}_{11}$ & $\mathrm{~V}_{2.5}+50 \% \mathrm{RDF}+\mathrm{B}_{0}$ & 74.75 & 73.47 & 71.66 & 69.89 & 17.93 & 8.78 & 6.65 & 6.43 & 15.53 & 15.83 & 16.25 & 15.80 & 7.170 & 5.760 & 4.765 & 4.315 \\
\hline $\mathrm{T}_{13}$ & $\mathrm{~F}_{10}+\mathrm{V}_{2.5}+\mathrm{B}_{1}$ & 75.47 & 74.15 & 72.26 & 70.67 & 19.35 & 9.39 & 8.14 & 8.01 & 17.65 & 17.98 & 18.28 & 17.20 & 7.660 & 6.240 & 5.050 & 4.515 \\
\hline $\mathrm{T}_{14}$ & $\mathrm{~F}_{0}+100 \% \mathrm{RDF}+\mathrm{B}_{1}$ & 75.37 & 73.49 & 72.15 & 70.85 & 19.28 & 8.76 & 7.54 & 7.32 & 16.23 & 16.55 & 16.83 & 16.05 & 7.260 & 5.750 & 4.790 & 4.200 \\
\hline $\mathrm{T}_{15}$ & $\mathrm{~F}_{0}+100 \% \mathrm{RDF}+\mathrm{B}_{0}$ & 74.68 & 73.37 & 71.90 & 69.25 & 18.89 & 8.01 & 6.91 & 6.68 & 16.23 & 16.45 & 16.65 & 16.05 & 6.650 & 4.710 & 3.805 & 3.230 \\
\hline & & Pooled & SEm & $\mathrm{CD}$ & CV \% & Pooled & SEm & $\mathrm{CD}$ & $\mathrm{CV} \%$ & Pooled & SEm & $\mathrm{CD}$ & CV \% & Pooled & SEm & CD & CV \% \\
\hline & Treatment: & & 0.408 & 0.360 & & & 0.263 & 0.797 & & & 0.182 & 0.553 & & & 0.022 & 0.062 & 0.610 \\
\hline & Storage Period : & & 0.129 & 0.255 & & & 0.110 & 0.494 & 4.26 & & 0.047 & 0.132 & 2.20 & & 0.011 & 0.032 & \\
\hline & PT : & & 0.498 & NS & & & 0.307 & NS & & & 0.252 & NS & & & 0.044 & 0.123 & \\
\hline
\end{tabular}


Table.2 Husk color, Husk drying, Kernel appearance and Sweetness as influenced by treatment and storage time at ambient condition. (Pooled data of two years i.e. the 2005-06 and 2006-07)

\begin{tabular}{|c|c|c|c|c|c|c|c|c|c|c|c|c|c|c|c|c|c|}
\hline \multirow{3}{*}{\multicolumn{2}{|c|}{ Treatments }} & \multicolumn{16}{|c|}{ Storage period (hours) } \\
\hline & & \multicolumn{4}{|c|}{ Husk color } & \multicolumn{4}{|c|}{ Husk drying } & \multicolumn{4}{|c|}{ Kernel denting } & \multicolumn{4}{|c|}{ Sweetness } \\
\hline & & O hrs & $24 \mathrm{hrs}$ & $48 \mathrm{hrs}$ & $72 \mathrm{hrs}$ & O hrs & $24 \mathrm{hrs}$ & $48 \mathrm{hrs}$ & $72 \mathrm{hrs}$ & $\mathrm{O}$ hrs & $24 \mathrm{hrs}$ & $48 \mathrm{hrs}$ & $72 \mathrm{hrs}$ & O hrs & $24 \mathrm{hrs}$ & $48 \mathrm{hrs}$ & $72 \mathrm{hrs}$ \\
\hline $\mathrm{T} 1$ & $\mathrm{~F} 10+100 \% \mathrm{RDF}+\mathrm{B} 0$ & 4.57 & 3.14 & 2.86 & 1.43 & 4.29 & 3.50 & 2.29 & 1.31 & 3.57 & 3.00 & 1.86 & 1.29 & 3.43 & 2.79 & 1.43 & 1.29 \\
\hline $\mathrm{T} 2$ & $\mathrm{~F} 10+100 \% \mathrm{RDF}+\mathrm{B} 1$ & 4.57 & 3.57 & 3.57 & 1.71 & 4.57 & 3.36 & 2.71 & 1.57 & 4.43 & 3.14 & 3.04 & 1.57 & 4.29 & 3.36 & 1.86 & 1.43 \\
\hline $\mathrm{T} 3$ & $\mathrm{~F} 10+75 \% \mathrm{RDF}+\mathrm{B} 0$ & 4.13 & 3.00 & 2.57 & 1.14 & 4.43 & 3.36 & 2.86 & 1.14 & 3.43 & 2.57 & 1.86 & 1.00 & 3.43 & 3.07 & 1.57 & 1.14 \\
\hline $\mathrm{T} 4$ & $\mathrm{~F} 10+75 \% \mathrm{RDF}+\mathrm{B} 1$ & 4.57 & 3.54 & 3.43 & 1.43 & 4.71 & 3.64 & 2.29 & 1.57 & 4.29 & 2.71 & 2.57 & 1.14 & 3.57 & 3.36 & 1.71 & 1.29 \\
\hline T5 & $\mathrm{F} 10+50 \% \mathrm{RDF}+\mathrm{B} 0$ & 4.14 & 3.57 & 3.14 & 1.00 & 4.14 & 3.07 & 2.43 & 1.14 & 4.00 & 2.71 & 1.86 & 1.00 & 3.14 & 2.64 & 1.43 & 1.14 \\
\hline T6 & $\mathrm{F} 10+50 \% \mathrm{RDF}+\mathrm{B} 1$ & 4.13 & 3.29 & 2.57 & 1.00 & 3.71 & 3.50 & 2.14 & 1.00 & 3.86 & 2.71 & 2.00 & 1.00 & 3.29 & 2.64 & 1.43 & 1.00 \\
\hline $\mathrm{T} 7$ & $\mathrm{~V} 2.5+100 \% \mathrm{RDF}+\mathrm{B} 0$ & 4.29 & 3.14 & 2.57 & 1.43 & 4.29 & 3.21 & 2.43 & 1.43 & 4.43 & 3.00 & 2.00 & 1.14 & 3.71 & 3.21 & 1.71 & 1.43 \\
\hline $\mathrm{T} 8$ & $\mathrm{~V} 2.5+100 \% \mathrm{RDF}+\mathrm{B} 1$ & 4.71 & 3.57 & 3.57 & 1.86 & 4.71 & 4.07 & 3.10 & 1.57 & 4.86 & 3.71 & 3.14 & 1.57 & 4.43 & 3.21 & 2.14 & 1.57 \\
\hline T9 & $\mathrm{V} 2.5+75 \% \mathrm{RDF}+\mathrm{B} 0$ & 4.57 & 3.00 & 2.86 & 1.14 & 4.14 & 3.93 & 2.43 & 1.29 & 3.43 & 2.86 & 2.29 & 1.14 & 3.00 & 2.79 & 1.71 & 1.29 \\
\hline $\mathrm{T} 10$ & $\mathrm{~V} 2.5+75 \% \mathrm{RDF}+\mathrm{B} 1$ & 4.57 & 3.43 & 3.29 & 1.71 & 4.71 & 3.64 & 2.71 & 1.29 & 4.29 & 3.43 & 3.04 & 1.29 & 4.14 & 3.36 & 2.00 & 1.57 \\
\hline $\mathrm{T} 11$ & $\mathrm{~V} 2.5+50 \% \mathrm{RDF}+\mathrm{B} 0$ & 4.29 & 3.14 & 3.14 & 1.00 & 4.43 & 2.64 & 2.00 & 1.00 & 4.00 & 2.57 & 1.86 & 1.14 & 3.71 & 2.93 & 2.14 & 1.00 \\
\hline $\mathrm{T} 12$ & $\mathrm{~V} 2.5+50 \% \mathrm{RDF}+\mathrm{B} 1$ & 4.14 & 3.00 & 2.29 & 1.00 & 4.14 & 3.50 & 2.43 & 1.43 & 3.57 & 2.71 & 2.14 & 1.00 & 3.43 & 2.79 & 1.43 & 1.00 \\
\hline $\mathrm{T} 13$ & $\mathrm{~F} 10+\mathrm{V} 2.5+\mathrm{B} 1$ & 4.71 & 3.43 & 3.14 & 1.43 & 4.57 & 4.07 & 2.43 & 1.00 & 4.43 & 3.29 & 3.04 & 1.29 & 4.57 & 3.50 & 2.29 & 1.43 \\
\hline $\mathrm{T} 14$ & $\mathrm{~F} 0+100 \% \mathrm{RDF}+\mathrm{B} 1$ & 4.43 & 3.57 & 3.14 & 1.00 & 4.57 & 3.50 & 2.29 & 1.14 & 4.00 & 2.86 & 1.71 & 1.00 & 3.57 & 2.93 & 1.71 & 1.00 \\
\hline $\mathrm{T} 15$ & $\mathrm{~F} 0+100 \% \mathrm{RDF}+\mathrm{B} 0$ & 4.13 & 3.50 & 3.00 & 1.00 & 4.29 & 3.50 & 2.57 & 1.14 & 3.86 & 2.43 & 2.14 & 1.00 & 3.15 & 2.29 & 1.43 & 1.00 \\
\hline & & \multirow[t]{4}{*}{ Pooled } & SEm & $\mathrm{CD}$ & $\mathrm{CV} \%$ & \multirow[t]{4}{*}{ Pooled } & SEm & $\mathrm{CD}$ & $\mathrm{CV} \%$ & \multirow[t]{4}{*}{ Pooled } & SEm & $\mathrm{CD}$ & $\mathrm{CV} \%$ & \multirow[t]{4}{*}{ Pooled } & SEm & $\mathrm{CD}$ & $\mathrm{CV} \%$ \\
\hline Trea & nent : & & 0.152 & 0.429 & \multirow{3}{*}{24.99} & & 0.144 & 0.406 & \multirow{3}{*}{26.25} & & 0.120 & 0.339 & \multirow{3}{*}{29.07} & & 0.17 & 0.478 & \multirow{3}{*}{32.39} \\
\hline Stora & Pe Period: & & 0.072 & 0.200 & & & 0.071 & 0.196 & & & 0.073 & 0.204 & & & 0.072 & 0.2 & \\
\hline PT : & & & 0.279 & NS & & & 0.274 & NS & & & 0.284 & NS & & & 0.279 & NS & \\
\hline
\end{tabular}




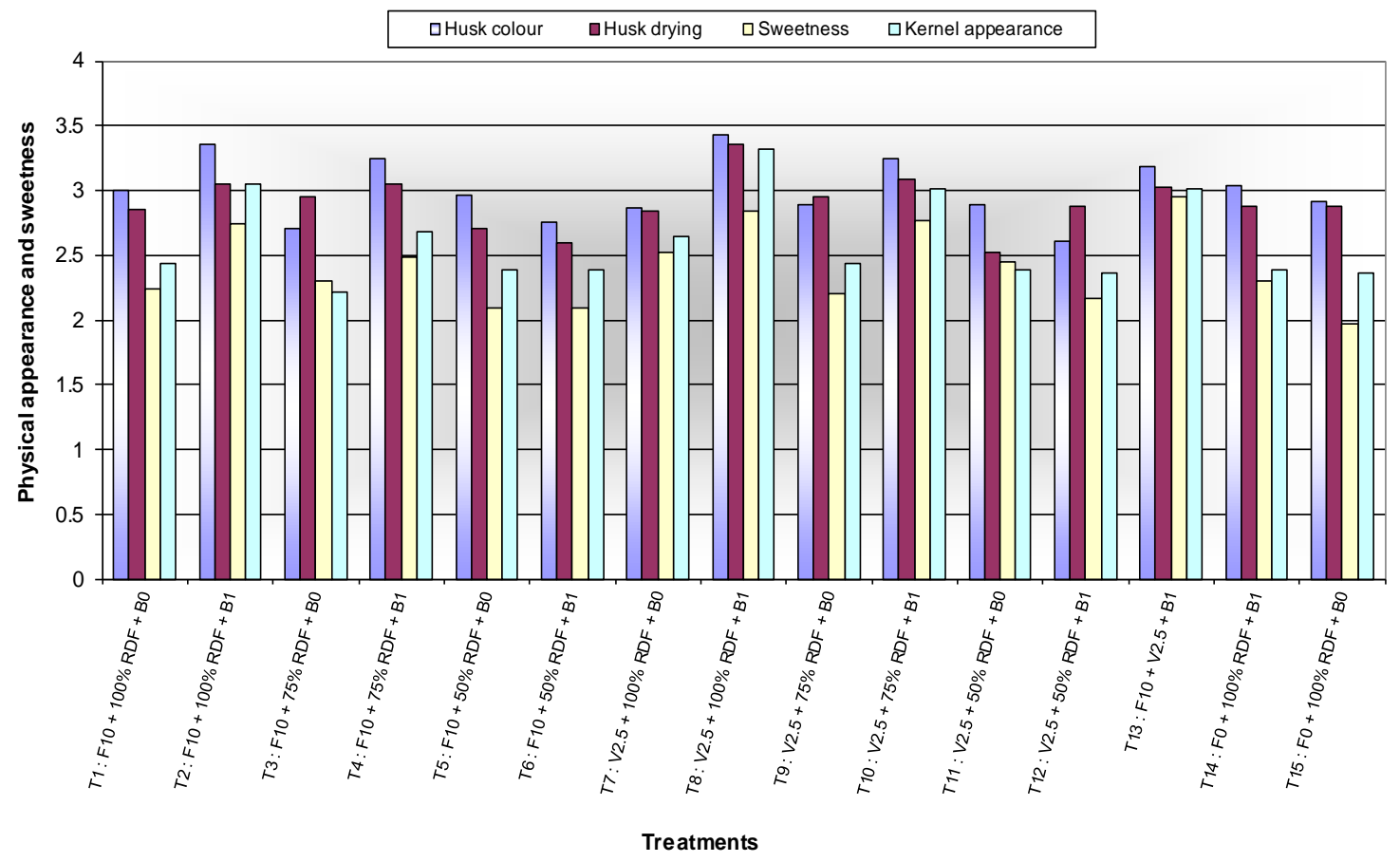

Fig. 4.12 : Husk colour, husk drying, sweetness and Kernel appearance as influenced by different treatments and storage time at ambient condition (pooled)

This might be due to increase in supply of $\mathrm{Zn}$ through organic fertilizer suppressed the effect on the activity of ascorbic acid oxidase, the enzymes responsible for the degradation of ascorbic acid content. Hailu et al., (2008) found increase in ascorbic acid and good retention quality throughout storage period of carrot with application of organics.

Significant drop in ascorbic acid content at different storage period at ambient condition observed during the course of storage in all the treatment at the end of $72 \mathrm{hrs}$ was 42.28 $\%$. The possible reason to be attributed might be due to the high and low temperature effects. Basically, low temperature delayed aging through reduced respiration rate and other undesirable metabolic changes. In contrast high temperature is known to promote enzymatic catalysts and lead to biochemical breakdown of compounds in fruits and vegetables. Lee and Kader (2000) also reported pre and post-harvest factors effect on Vit $\mathrm{C}$ and found organic fertilizers had beneficial effect on Vit $\mathrm{C}$ the interaction of pre harvest treatment and post-harvest storage period resulted in significant differences in ascorbic acid content through the storage period.

\section{Sensory qualities}

Data presented in table 2 showed significant variation among treatments and storage period. Husk colour (appearance) was significantly better in treatment $\mathrm{T}_{8}\left(\mathrm{~V}_{2.5}+\right.$ $\left.100 \% \mathrm{RDF}+\mathrm{B}_{1}\right)$ and $\mathrm{T}_{13}\left(\mathrm{~V}_{2.5}+75 \% \mathrm{RDF}+\right.$ $B_{1}$ ) than control $T_{15}$ at harvest. Similar trend was observed in husk drying in the treatment $\mathrm{T}_{8}$ and $\mathrm{T}_{10}$ and were significantly better in appearance as compared to control $\mathrm{T}_{15}$ and rest of the treatments. This might be effect of higher nitrogen and $\mathrm{P}, \mathrm{K}$ and other micro nutrient availability from organic manure (vermicompost and biofertilizers) ultimately resulted in improving quality. 
All the treatments observed decreasing trend with respect to drying of husk and denting of kernel and had below 2.0 rating which has indicated pale green to yellow colour and dried out of major portions of sweet corn at the end of $72 \mathrm{hrs}$., of storage. This might be due to high temperature and less relative humidity which enhance transpiration process thereby water loss resulting in drying and wilting of husks. These results are in close agreement with that of Showalter (1963), Deak et al., (1987) in sweet corn and Paull and Chen (1987) in Litchi.

Data presented in table 2 of sweetness revealed significant variation among the treatments and storage period in sweet corn. At harvest treatment $\mathrm{T}_{13}$ followed by $\mathrm{T}_{8}, \mathrm{~T}_{2}$ and $\mathrm{T}_{10}$ were significantly found to be have excellent sweetness over control $\mathrm{T}_{15}$. This might be a reason of higher total sugar and sugar acid ratio. These results were consistence with the result of Evenson and Boyer (1980), who reported that the sensory scores become increasingly well correlated with sugar content. Similar results were observed by Olsen et al., (1990) in sweet corn. Significantly gradual decline in sweetness was observed from initial to end of storage period (at $72 \mathrm{hrs}$ ) in all the treatments.

Data presented in table 2 of kernel denting revealed significant variation among treatments and storage period during the study. At harvest treatment $\mathrm{T}_{8}, \mathrm{~T}_{10}$ and $\mathrm{T}_{2}$ were found significantly better kernel appearance with fresh bright colour than treatment $\mathrm{T}_{3}$ and $\mathrm{T}_{9}$. Treatment $\mathrm{T}_{8}, \mathrm{~T}_{10}$ and $\mathrm{T}_{13}$ significantly maintained reasonably bright appearance and no denting on kernel of cob of sweet corn upto end of $48 \mathrm{hrs}$ than rest of the treatments. At the end of $72 \mathrm{hrs}$ of storage, all the treatments had denting appearance. The kernel appearance and denting of kernel were closely related with moisture content. This might be due to the leafy anatomical features of corn in the husk for conducive to rapid water loss through transpiration process under low humidity conditions during harvesting and handling. These results are confirmed the earlier findings of Showalter (1963) and Brecht et al., (1990) in sweet corn.

Combined application of bio organics and inorganic fertilizers had influenced the quality of sweet corn both at harvest and during storage period under ambient conditions. The moisture content, total soluble solids, total soluble sugar, ascorbic acid and sensory qualities of sweet corn were significantly affected by the different pre harvest treatments both at harvest and during the different storage period at ambient conditions. In all the cases, the best post-harvest quality of sweet corn was obtained from pre harvest treatment $T_{8}$, which had retained significantly higher total sugar, ascorbic acid and fresh physical appearance up to $24 \mathrm{hrs}$., at ambient storage condition and was at par with $\mathrm{T}_{10}$ and $\mathrm{T}_{13}$ in case of TSS, ascorbic acid content than rest of the treatments and can be remained with acceptable nutritional quality up to 24 hrs at ambient storage. From the above results it can be concluded that post-harvest quality of rabi sweet corn crop can be obtained with an application of vermicompost @ 2.5 t ha-1 along with $100 \%$ RDF and seed inoculation with biofertilizers (Azotobacter-1 + PSB1-16) (T8) and can be remained with acceptable nutritional quality up to $24 \mathrm{hrs}$ at ambient storage.

\section{References}

Appleman, C. O., and John. M. Arthur. 1919. Carbohydrate metabolism in green sweet corn during storage at different temperatures. J. of Agri. Res., 17(4): 137152.

Barans, B. J., and Wisniewaki, J. 1998. Effect of utilization of unconventional multicomponent fertilizers on chosen properties of light soil. Agricultura, 72: 11- 
20.

Beadle, G.W., 1939. Teosinte and origin of maize Journal of Heredity., 30: 245-247.

Brecht, J. K., Sargent, S. A., Hochmukuth, R. C.and Tervola, R. S. 1990. Post-harvest quality of super sweet (sh2) sweet corn cultivars, Hort.Soc.103:283-288.

Chaudhary, D. R., Bhandari, S. C. and Shukla, L. M. (2004). Role of vermicompost in sustainable Agriculture a review. Agric. Rev., 25(1): 29-39.

Deak, T., Heaton, E. K., Huny, P. C. and Beauchat, L. R. 1987. Extending the shelf life of fresh sweet corn by shrink, wrapping, refrigeration and irradiation. Journal of Food Science 52 (6): 1625-1631.

Duncan D.B., 1955. New Multiple Range and Multiple F Tests. Biometrics, 11:1-42.

Evenson, K. B., and Boyer, C. D. 1986. Carbohydrate composition and sensory quality of fresh and stored sweet corn. J. American Soc. Hort. Sci., 111: 734-738.

Franscistte, W., David, F.B. and Robert, M.D. 1971. The estimation of total soluble carbohydrate in cauliflower tissue. Experiments in plant physiology. Van Nostrand Reinhold Camp. New York. pp: 16.

Garwood, D.L., and MaArdle, F.C. 1976. Postharvest carbohydrate transformations and processed quality of high sugar maize genotypes. J. Amer. Soc. Hort. Sci., 101 (4): 400-404.

Hailu, S., Seyoum, T. and Dechassa, N. 2008. Effect of combined application of organic $\mathrm{P}$ and inorganic $\mathrm{N}$ fertilizers on post-harvest quality of carrot. African Journal of Biotechnology, 7 (13):2187-2196

Lee, S. K., and Kader, A. A. 2000. Preharvest and post-harvest factors influencing vitamin $\mathrm{C}$ content of horticultural crops. Post-Harvest Biol.Technol, 20: 207-220.

Melkanu, M., Seyoum, T. and Woldetsadik, K. 2008. Effect of pre and post-harvest treatments on changes in sugar content of tomato. African Journal of Biotechnology, 7 (8):1139-1144.

Olsen, J.K., Giles, J.F., and Jordan. R.A. 1990. Postharvest carbohydrate changes and sensory quality of three sweet corn cultivars. Scientia Horticulture., 44: 179189.

Paull, C. R., and Chen, N. J. 1987. Effect of storage temperature and wrapping on quality characteristics of litchi fruit. Scientia Horticulture., 33: 223-236.

Salunkhe, D.R., and Kadan, S. S. 2005. Hand Book of Vegetable Science and Technology Production, Composition and Processing. Marcell Dekkar Publication, New York.

Showalter, R. K., 1963. Shank and husk trimming effects on sweet corn storage life. Florida State Horticultural society, 76: 308-512.

Thakur, K.S., Lal, B. B. and Sharma, R. M. 2002. Effect of different post-harvest and storage condition on the fruit quality of Kinnow. J. Food Sci. Techol., 39 (6): 609-618.

Vani Sudha, 2002. Effect of pre harvest spray of growth regulator on growth, yield and postharvest handling methods on shelf of baby corn. Ph.D. Thesis. Dept. of Hort., College of Agri. N.G.Ranga Agril. Univesity. Hyderbad.

Wann, E.V., Brown, G.B. and Hills W.A. 1971.Genetic modifications of sweet corn quality. J.Amer, Soc. Hort. Sci., 96:441444.

\section{How to cite this article:}

Bharat H. Panchal, V.K. Patel and Khimani, R.A. 2017. Influence of Pre Harvest Factor on Post-Harvest Quality of Green Sweet Corn at Ambient Condition (Zea mays convar. saccharata. rugosa) Cultivar, Madhuri. Int.J.Curr.Microbiol.App.Sci. 6(10): 30-38. doi: https://doi.org/10.20546/ijcmas.2017.610.005 